\title{
Research on the Training of College Students' Entrepreneurial Ability in Private Colleges and Universities Based on the School-enterprise Cooperation Mode
}

\author{
Shucui Shi ${ }^{a}$, Chunlei Han ${ }^{b}$ and Qiang Han ${ }^{c}$ \\ Qingdao Huanghai University, Qingdao 266427, China \\ a121745182@qq.com, bchentongab@163.com, c448077855@qq.com
}

Keywords: private colleges and universities; school enterprise cooperation; talent training mode.

\begin{abstract}
In recent years, in order to change the current situation of college students' difficulties in entrepreneurship, China has introduced the talent training mode of school-enterprise cooperation. However, how private colleges and universities to train college students' entrepreneurial ability still a serious problem under the school-enterprise cooperation. This paper analyses the impact of school-enterprise cooperation on college students' entrepreneurship ability from the concept and purpose of school-enterprise cooperation, and further explore how to improve the entrepreneurial ability of private college students under the background of school-enterprise cooperation. Private colleges and universities aim at training practical, innovative, entrepreneurial talents as the center, school-enterprise cooperation mode can effectively improve the entrepreneurial ability of college students. This paper studies the training of private college students' entrepreneurial ability under the view of school-enterprise cooperation, through the analysis of the significance and deficiencies of this mode, this paper proposes the perfect measures for the talent training mechanism of the school-enterprise cooperation mode, so can better promote the training of students' entrepreneurial ability.
\end{abstract}

\section{Introduction}

The school-enterprise cooperation is based on the market and social demand, the school and enterprise two different educational environments and teaching resources are comprehensively utilized, the organic combination of school classroom teaching and enterprise practice is used and train the students' entrepreneurial quality in a planned way. The school-enterprise cooperation is guided by the market and social needs change the traditional way of classroom teaching, truly realize the open education with the theory and practice, and it is undoubtedly the most effective way to train students' entrepreneurial ability. Although the school-enterprise cooperation model has the advantages in training practical, innovative and entrepreneurial talents, because private colleges and enterprises lack a reasonable cooperation forms and cooperation experience, so there are many problems in the process of school-enterprise cooperation, the training effect is not good.

\section{The Significance of School-enterprise Cooperation Mode for Training Entrepreneurial Talents in Private Colleges and Universities}

The essence of entrepreneurship education is practice, so the practical conditions are the necessary basis for entrepreneurship education in private colleges and universities. In the form of entrepreneurship education, the reason why many schools choose to "talk empty" is mainly because lack practical training conditions and approaches. Enterprises also need the technology and talents provided by universities. The talent training mechanism based on the school-enterprise cooperation model can simultaneously meet the internal needs of the universities and the enterprises during their development. First of all, the enterprise provides a suitable practice environment for the theoretical knowledge of the private students, so that the students can apply the knowledge to the practical operation to improve the students' practical and innovation ability; the production equipment and the 
experience in the enterprises can provide better practice opportunities for the students, realize the combination of students' theory and practice, and improve the students' comprehensive ability; the industry-university-research projects jointly carried out by the schools and enterprises can improve the students' application and practical ability, thus promoting the improvement of the efficiency and the teaching quality of the private colleges and universities. Secondly, universities provide more high-quality and practical talents for enterprises, and provide support for enterprises in technology and knowledge. In addition, in the process of cooperation, the two sides can set up their own good image, promote the improvement of the core competitiveness of the enterprises and the better development of the private colleges and universities. For example, the private colleges and universities and enterprises can work together to build college students' entrepreneurial platform, the enterprise provide brand, technology and experience, the school provide stores, personnel and so on. By co-construction and co-management, we can achieve the training of entrepreneurial talents and achieve win-win cooperation.

\section{The Deficiency of Current School-enterprise Cooperation Mode}

In general, the current cooperative mode of private universities and enterprises is still in a shallow level, and the role of training the innovative and entrepreneurial talents is limited. There are shortcomings in the current mode of school enterprise cooperation: first, private colleges cannot fully comprehend the deep meaning of school-enterprise cooperation, only attention to the short-term goals are paid in the process of planning of school-enterprise cooperation activities, and it is not able to think from the training level of entrepreneurial talents. As a result, the school-enterprise cooperation activities are not consistent in teaching plans and other aspects, and the role of training entrepreneurial talent training cannot be fully utilized. Secondly, incentives which enterprises participate in the school-enterprise cooperation mode is not enough, the college generally pays more attention to the development of itself, and neglects the development needs of the enterprise, cause enterprise lack motivation and participation in the school-enterprise cooperation mode. Thirdly, the flexibility and effectiveness of the cooperation mechanism between private universities and enterprises is poor, resulting in the lack of long-term planning between universities and enterprises in the cooperation process, and cannot achieve a deeper level of development [1].

\section{Countermeasures and Thinking}

\subsection{Change Talent Training Mode}

The colleges form the concept of open education, adhere to take vocational education talent training mode for colleges students, mainly train the jobs for-line work. Because the newly graduated students must be cultivated and promoted at the grassroots level, they can gradually be valued and promoted by enterprises. Even the entrepreneur must be familiar with the way of working at the grassroots level, accumulate work experience and professional skills, and then be able to have the courage and strength to start a business. Schools should go out of the original enclosed talent training mode, strengthen the communication with outside the school, train students based on the actual needs of talent market, and lead the students according to the possibility development of the students. Always adhere to the "together with students" education idea, the students as individual who is unique, full of life, free, happy, like challenge, pursue success, teach students to learn life, learn to study, work steadfast and honest.

\section{2. Adhere to Social Practice Projects and Expand Entrepreneurship Horizon}

Faced with the plight of the college student's overall quality drop, the colleges and universities must adhere to quality education, but also carry out solid and effective social practice project, train students to become independent, autonomous, strong, mature, successful people. Social practice and school-enterprise cooperation pattern is not a slogan and an innovation, it needs the guidance, supervision and management of the school, and only in this way can form standard practice patterns. The colleges and universities should adhere to social practice in winter and summer vacation every 
semester, and fully mobilizes and organizes before practice, different majors should be treated differently, and students should be arranged to practice in enterprise which fit majors. The schools should arrange the work to boys and girls specifically and arrange different jobs according to the characteristics of students. Instructors should go to the enterprise to become teachers, always arrive at the scene to solve the problem of students at any time, understand the student's body and mind status into the dormitory every day, truly realize "together with students" management idea. At the same time, we will create a self-management, self-education and self-service atmosphere for students, so as to realize the win-win results which students learn and enterprise gain profits. At present, the standardized practice system and supporting documents have been formed to guarantee the development and efficacy of social practice project. The essence of entrepreneurship education is its practicality, good entrepreneurial quality and ability can only be cultivated and improved in the entrepreneurship practice, and the enterprise is the best classroom to cultivate students' entrepreneurial will. After in-depth enterprise practice, the school can understand the needs of the talent market, so as to train talents suitable for different positions based on the talent market demand, students can broaden their horizons, have innovative spirit, improve their entrepreneurial ability, and become a talented person who can adapt to the social development.

\subsection{Train Students' Organizational Management Ability and Entrepreneurial Team Awareness.}

The interpersonal relationship is importance to entrepreneurship, entrepreneurs need a team to set up a company, establish a professional partnership with fraternity, and help others to get recommendation. The interpersonal relationships are the primary criterion for examining entrepreneurs, because only through communication can extract the essence. Therefore, at the beginning of admission, the colleges should attach importance to the cultivation of students' interpersonal relationship and organizational management ability. For example, suggest that students should join 1-2 student clubs according to their own interests, encourage students to actively campaign the student union, arrange proper positions according to students' specialty, personality. Promote students' self-education, self-management, and self-service consciousness education, as far as possible; try to exercise students' management and organizing ability according to local conditions as far as possible, achieve "it's better to teach a man fishing than to give him fish". Especially in the process of enterprise practice, the colleges students become the worker role completely from student role, face more conflicts and problems. At this time the teacher must encourage them to think positively the relationship between individuals and enterprises, effectively handle conflict with the identity of the enterprise identity and work, use wisdom to help self and classmates gain interests without hurting others, at the same time win the respect and appreciation of students, teachers and enterprises, set up a team consciousness, and accumulate rich experience for future entrepreneurship and team management.

\subsection{Train Students' Independent Learning Ability and Obtain Entrepreneurial Competitive Capital}

Autonomous learning ability is that people actively absorb and master knowledge, according to certain social and personal value demand. The enterprises or individuals only can have strong and continuous learning ability, can achieve success and remain brilliant. Under the same conditions, whoever is ahead of the competitor will be the winner. Therefore, autonomous learning ability is the competitive capital of entrepreneurship. Fully mobilize the enthusiasm and initiative of college students to start their own businesses can improve their entrepreneurial ability [5]. According to the interpersonal relationship theory, the key to cultivate college students' independent study is the harmonious relationship between teachers and students [6]. The democratic and harmonious atmosphere is easy to cultivate children's self-confidence and self-esteem, which is the prerequisite and essential condition for starting a business. School-enterprise cooperation class in class, practice, teachers treat students as their work partners, intentionally obscure the authority role of the teacher, reduce the college students' mental pressure and psychological barriers, and encourage students' self-expression in the equal and harmonious interpersonal environment, inspire students' ability of independent thinking. Free and vivid teaching atmosphere enables students' entrepreneurial thinking 
to sprout. In the study, students build a group study with common desire and systematic thinking, and constantly improve themselves and go beyond themselves in the efforts of the group.

\subsection{Implement Business Plan in Teaching Practice}

The teachers who in school-enterprise cooperation class, they have solid professional knowledge, also must practice relevant cooperative enterprises, and participate in certain business education teacher training courses. In this way, the trained teachers have solid professional theoretical knowledge, master education teaching law and professional qualification certificate, and are familiar with the practice of enterprise production management. Some enterprises which cooperate with college will arrange some experts to college for short-term practice teaching, the experts are the student mentors, promote the discipline development the entrepreneurship education, and become students' intelligence guarantee of. When school-enterprise cooperation enterprises need as a strong point for training students, the aim of school vocational education is achieved, meet the needs of the talents in the social market, enhance the student's entrepreneurial psychological quality, and promote the students to control the market ability, realize the training strategy of training teachers.

\section{Conclusion}

The private colleges and universities should start from the talent training in school-enterprise cooperation mode, to promote students more deeply involved in the enterprise's production practice [4]. With the continuous deepening of school-enterprise cooperation, on the one hand, it can improve students' entrepreneurial ability; on the other hand, it can continuously promote development force of the enterprise. The private colleges and universities should provide corresponding support for scientific research, personnel, products of enterprises, etc., promote the cooperation between enterprises and universities, and provide better conditions for students' entrepreneurship.

\section{References}

[1]. Jin Genzhong. The exploration and practice of the training of innovation and entrepreneurship ability of high vocational students in school-enterprise cooperation mode [J], Mechanical Vocational Education, 2014, 06 (15): 57-59.

[2]. Sun Hui. "School-enterprise cooperation" promote entrepreneurship education training mode [J]. Examination Weekly, 2009(34): 202.

[3]. Xiao Yun, Du Yi. Construction of college students' employability: the perspective of governmental responsibility [J], Contemporary Youth Research, 2008 (4).

[4]. Jin Ting. Empirical research on the structure and current situation of employment of contemporary college students[J]. Journal of Northeast Normal University (philosophy and social science edition), 2013(11):237-239. 